\title{
MENGUAK SUKSES WIRAUSAHA PETERNAKAN BURUNG LOVEBIRD ( Study Kasus Usaha Heli Lovebird di Cinde Raya Timur Semarang)
}

\author{
Zarah Nurkarimah \\ Edy Mulyantomo \\ Edy Suryawardana
}

Fakulitas Ekonomi - Universitas Semarang

Diterima: Februari 2019, Disetujui: Maret 2019. Dipublikasikan: April 2019

\begin{abstract}
This study aims to find out about the interest of farmers in breeding lovebird birds, knowing the development of lovebird birds and non-financial feasibility in lovebird raising.This study uses a qualitative descriptive approach. As for the research object, namely the Business Residence owned by Mr. Heli Purwanto using 5 informants who assisted in the research.Breeding chirping birds such as lovebird (Agapornis) is now increasingly being glimpsed by chirping hobbies in various regions. The skyrocketing lovebird selling price also triggers breeders to develop it to the fullest.

As for the results it can be concluded that lovebird breeding must have a lot of experience from the types of lovebird species, prices that can be of value to the beauty of their feathers, and how to develop lovebird birds that can be seen from non financial aspects. Likewise opportunities for meeting the demands of collectors and hobbyists encourage this business to run a business. The purpose of this study was to analyze the feasibility of a Lovebird cultivation business with a business case study of Mr. Heli in terms of non-financial aspects. Data processing was carried out qualitatively. Based on the results of the analysis of the non-financial aspects of the business Mr. Heli deserves to be run because there are no obstacles in the aspects of the market, technical aspects, management aspects, legal aspects, and social aspects of the environment.
\end{abstract}

Keywords: Opportunities, Non-Financial Analysis, maintenance of lovebird

\begin{abstract}
ABSTRAK
Penelitian ini bertujuan untuk mengetahui tentang ketertarikan peternak dalam berternak burung lovebird,mengetahui perkembangan burung lovebird dan kelayakan Non finansial dalam berternak lovebird.Penelitianinimenggunakan pendekatan deskritif kualitatif.Adapunobyekpenelitianyaitu kediaman Usaha milik Bapak Heli Purwanto menggunakan 5 informan yang membantudalampenelitian. Beternak burung kicauan seperti lovebird (Agapornis) saat ini semakin dilirik oleh para penghobi burung kicauan diberbagai daerah. Meroketnya harga jual lovebird juga menjadi pemicu para penangkar untuk mengembangkannya secara maksimal.Adapunhasilnyadapat disimpulkanbahwaberternak burung lovebird harus mempunyai banyak pengalaman dari mulai jenis jenis burung lovebird,harga yang bisa di nilai dari keindahan bulunya ,dan cara mengembangkan burung lovebird yang dapat di lihat dari Aspek-aspek Non Finansialnya.Demikian pula peluang dalam memenuhi permintaan dari pengepul dan penghobi mendorong bisnis ini untuk menjalankan usaha.Tujuan penelitian ini adalah menganalisis kelayakan usaha budidaya burung Lovebird dengan studi kasus usaha Bapak Heli ditinjau dari aspek non finansial.Pengolahan data dilakukan secara kualitatif.Berdasarkan hasil analisis aspek non finansial usaha Bapak Heli layak untuk dijalankan karena tidak ada kendala dalam aspek pasar, aspek teknis, aspek manajemen, aspek hukum, dan aspek sosial lingkungan.

Kata Kunci : Peluang,Analisis Non Finansial,pemeliharaan lovebird
\end{abstract}




\section{PENDAHULUAN}

Indonesia merupakan negara yang mempunyai kelestarian fauna dengan beragam jenis salah satunya yaitu burung Berkicau . Para penghobi burung berkicau mungkin sudah tidak asing lagi mendengar nama burung lovebird.

Beternak burung kicauan seperti lovebird (Agapornis) saat ini semakin dilirik oleh para penghobi burung kicauan diberbagai daerah.Meroketnya harga jual lovebird juga menjadi pemicu para penangkar untuk mengembangkannya secara maksimal. Burung Lovebird juga menjadi topik yang saat ini sedang trend diperbincangkan dalam forum-forum offline maupun forum-forum online di internet. Faktor kepopuleran inilah yang menyebabkan harga burung tersebut

Melonjak.Salah satunya yang menjadi objek penelitian adalah jenis burung yang ada pada usaha HELI LOVEBIRD yang merupakan salah satu pemilik usaha dari banyak nya pengusaha peternak burung lovebirdlainnya yang mana sudah merasakan hasil usahanya tersebut.Awal pemikirannya terjun kedunia peternakan yaitu yang mana bapak Heli si pemilik burung HELI LOVEBIRD sudah mulai bosan dengan dunia kerja yang mana terlalu banyak aturan. Dari sana Bapak Heli mempunyai pemikiran ingin berwirausaha yaitu usaha ternak burung lovebird pada awal berternak pemilik hanya mempunyai 2 pasang lovebird dan di tahun 2015 pemilik sudah mempunyai 25 pasang atau 50 ekor lovebird atas mengumpulkan dana sedikit demi sedikit untuk membeli lovebird di saat itu pula usahanya sudah bisa di kebangkan dan juga sudah bisa balik modal.

Meskipun demikian,terdapat masalah yang dapat menghambat usaha peternakan burung LB (Lovebird), diantaranya adalah terkadang indukan LB(Lovebird) yang mana suka merusak telurnya sendiri dikarenakan kurang telitinya peternak dalam pemberian pakannya yang menyebabkan indukan menyerang telurnya sendiri dan menyebabkan gagal panen, peternak juga harus sering memantau perkembangan telur di dalam kandang.kondisi lingkungan sangkar diusahakan nyaman dari gangguan hewan pengganggu seperti tikus,kadal,kucing dan lain lain.berdasarkan masalah masalah tersebut menyebabkan ketidakstabilan produksi oleh sebab itu, analisis usaha ternak Lovebirdmenjadi bahasan menarik dalam penelitian ini.Berikut adalah Hasil keuntungan Per bulan yang didapat oleh Perusahaan HELI LOVEBIRD. 
Tabel 1

Data penjualan lovebirdParblue

Tahun2016

\begin{tabular}{|c|c|c|c|}
\hline Bulan & penjualan & Harga /ekor & Jumlah Harga \\
\hline Januari & 10 ekor & @2.000.000 & Rp 20.000.000 \\
\hline Februari & 9 ekor & @ 2.000.000 & Rp 18.000.000 \\
\hline Maret & 9 ekor & @ 2.000.000 & Rp 18.000.000 \\
\hline April & 10 ekor & @ 1.500.000 & Rp 15.000.000 \\
\hline Mei & 8 ekor & @ 1.500.000 & Rp 12.000.000 \\
\hline Juni & 8 ekor & @ 1.800 .000 & Rp 14.400.000 \\
\hline Juli & 9 ekor & @ 1.800 .000 & Rp 16.200.000 \\
\hline Agustus & 10 ekor & @ 1.800 .000 & Rp 18.000.000 \\
\hline September & 11 ekor & @ 2.000.000 & Rp 22.000.000 \\
\hline Oktober & 11 ekor & @ 2.000.000 & Rp 22.000.000 \\
\hline November & 14 ekor & @ 2.000.000 & $\operatorname{Rp} 28.000 .000$ \\
\hline Desember & 14 ekor & @ 2.000.000 & Rp 28.000.000 \\
\hline TOTAL & & & Rp231.600.000 \\
\hline
\end{tabular}

Sumber : Usaha Heli Lovebird

bulan januari - maret penjualan harga per ekor masih stabil tapi di bulan AprilAgustus harga loverbird mengalami penurunan sekitar $25 \%$, namun di bulan berikutnya September-Desember harga loverbird naik kembali stabil penjualan LB (loverbird) juga dirasa masih naik turun .

Berdasarkan uraian latar belakang masalah di atas maka pokok masalah yang dihadapi dalam penelitian ini diuraikan sebagai berikut ini:

1. Bagaimana ketertarikan Bapak Heli dalam berternak burung Lovebird?

2. Bagaimana Pengembangan burung Lovebird ?

3. Bagaimana Analisis Kelayakan Bisnis Non Finansialburung Lovebird ?

Berdasarkan identifikasi masalah diatas, maka peneliti menetapkan batasan masalah sebagaiberikut :

1. Untuk mengetahui Ketertarikan Berternak Lovebird oleh Bapak Heli

2. Untuk mengetahui Pengembangan burung Lovebird

3. Untuk mengetahui Analisis Kelayakan Bisnis Non Finansial burung Lovebird 


\section{TELAAH LITERATUR}

\section{Pengertian Usaha peternakan}

Usaha Peternakan dalam Undang-Undang Pokok kehewanan, Undang-Undang Nomor 6 Tahun 1967, tentang ketentuan-ketentuan pokok peternakan dan kesehatan hewan mengemukakan bahwa ternak adalah hewan piara yang kehidupannya yakni mengenai tempat perkembangbiakan serta manfaatnya diatur dan diawasi oleh manusia dan dipelihara khusus sebagai penghasil bahan-bahan dan jasa-jasa yang berguna bagi kepentingan hidup manusia. Peternak adalah orang atau badan hukum dan atau buruh peternakan yang mata pencaharian nya sebagian atau seluruhnya bersumber kepada peternakan. Sedangkan peternakan atau Usaha Peternakan adalah pengusahaan atau pembudidayaan ternak dengan segala fasilitas penunjang bagi kehidupan ternak (Abbas, Hanif 2005)

\section{Jenis-jenis usaha peternakan di Indonesia}

Menurut Charoen(2006), Atas dasar tingkat jumlah produksi, teknologi yang dipakai, banyaknya hasil produksi yang dipasarkan, maka jenis usaha Peternakan di Indonesia terdiri dari :

1) Peternakan tradisional

Peternakan tradisional memiliki ciri-ciri iumlah ternak sedikit, input teknologi rendah, tenaga kerja keluarga dan profit rendah.

2) Peternakan backyard

Peternakan backyard memiliki ciri-ciri jumlah ternak sedikit, input teknologi mulai tinggi, tenaga kerja keluarga dan profit sedang. Diwakili peternak ayam ras dan sapi perah

3) Peternakan modern

Peternakan moderndengan ciri-ciri jumlah ternak banyak, input teknologi tinggi, tenaga kerja spesifik bidang peternakan dan profit tinggi.

\section{Usaha Peternakan Burung Lovebird}

\subsubsection{Pengertian burung Lovebird}

Lovebird merupakan salah satu burung dari genus agapornis.Secara harfiah, Agapornis berasal dari bahasa yunani yakni agape yang berarti cinta dan ornis yang berarti burung. Burung lovebird ini berasal dari benua afrika dan madagaskar.Seperti 
namanya, burung ini dapat memikat hati dan dicintai banyak orang.Lovebird atau burung cinta ini memiliki banyak kelebihan untuk dijadikan sebagai hewan peliharaan.Suara kicau dan variasi warna bulunya yang indah adalah ciri khas lovebird yang tidak dimiliki oleh burung lainnya (Dewi, 2011).

\section{Memilih calon indukan}

1. Postur tubuh atau badan lovebird antara kepala, leher, ekor dan kaki perfect dan proposional

2. Sayap mengapit kuat dan kaki mempunyai daya cengkram yang cukup kuat pula

3. Pergerakan lovebird aktif, lincah dan yang terpenting burung lovebird yang dipilih sangat agresif

4. Bulu rapat, bersih dan tidak kusam

5. Lovebird memperlihatkan rasa rakus terhadap makanan

6. Mata lovebird cerah dan bersinar dengan sorot mata yang tajam dan tidak layu.

\subsubsection{Menentukan Jenis Kelamin}

1. Bentuk Paruh Lovebird

Apabila Lovebird yang anda punya memiliki bentuk yang tumpul sudah dapat dipastikan burung lovebird anda berjenis kelamin betina namun sebaliknya jika anda mendapati lovebird anda berbentuk lancip berarti lovebird anda jenis kelamin nya jantan.

\section{Bentuk Tubuh Lovebird}

Apabila anda menemui burung lovebird dengan bentuk badan nya kecil dan ramping anda sudah bisa menebak bahwa burung lovebird tersebut jenis kelamin nya betina, kalaupun jantan memiliki bentuk badan yang gempal dan agak sedikit besar berisi badan nya.

\section{Hasil Usaha}

Hasilmembantu menggambarkan tingkat nisbah/rasio keuntungan yang diperoleh dari pemberian masukan terhadap lahan untuk usaha tani.Dalam praktik, hasil sering kali dikonversi menjadi nilai ekonomi (nilai jual) per satuan luas untuk membantu perhitungan keuntungan ekonomi. 


\section{Kelayakan}

Menurut Kasmir (2009) pengertian kelayakan usahatani adalah penelitian yang dilakukan secara mendalam untuk menentukan apakah usaha yang akan dijalankan akan memberikan manfaat yang lebih besar dibandingkan dengan biaya yang akan dikeluarkan. Untuk mengetahui usahatani menguntungkan atau tidak secara ekonomi dapat dianalisis dengan menggunakan perbandingan antara penerimaan dengan biaya.

\section{METODE PENELITIAN}

\section{Rancangan Penelitian}

Penelitian ini menggunakan metode penelitian deskriptif kualitatif yang berdasarkan pada fenomena, gejala, fakta, atau informasi sosial yang akurat. Bogdan dan Taylor (dalam Moleong. 2010: 4) mengatakan bahwa prosedur penelitian yang menghasilkan data deskriptif berupa kata-kata tertulis atau lisan dari orang-orang atau perilaku yang dapat diamati. Jumlah informan dalam penelitian ini tidak ditentukan jumlahnya. Dengan kata lain, jumlah informannya ditentukan sesuai dengan keperluan penelitian.

\section{Objek Penelitian}

Obyek penelitian dalam pembahasan skripsi ini adalah Usaha peternakan Heli Lovebird dan Pasar Burung Karimata yang mana banyak penghoby ternak Burung LB (Lovebird) .Sumber data yang diteliti yaitu perilaku masyarakat dalam ketertarikan ternak burung LB (Lovebird).Dilakukan juga pengambilan foto mengenai kondisi Usaha para wirausaha dalam melakukan transaksi jual beli burung LB (Lovebird) Foto tersebut sebagai pendukung data observasi mengenai ketertarikan dan pengembangan usaha burung LB(lovebird) .Dari pertimbangan tersebut di dapat 5 informan kunci yaitu Bapak Heli (Pemilik Usaha),Bapak Ghanur (Pengepul 1), Bapak Suendar (pengepul 2),Ko Daniel (Pembeli 1),Aan Noya (Pembeli 2).

\section{Jenis Data Penelitian}

Penelitian ini menggunakan data primer dan data sekunder.Perolehan data bertumpu pada teknik triangulasi data dimana data di hasilkan dari 3 metode yaitu interview, participant observation dan document record. 


\section{Teknik Analisis Data}

Teknik analisis data pada penelitian ini menggunakan model Miles dan Hubberman (1994) yang terdapat 3 tahap,meliputi tahap reduksi data,tahap display data sertatahap penarikan kesimpilan dan verifikasi data.Dalam penelitian kualitatifyang harus diuji adalah data yang di dapatkan dari informan.Untuk menguji keabsahan data, peneliti menggunakan metode triangulasi sumber dan triangulasi metode.

\section{HASIL DAN PEMBAHASAN}

Pada bab ini menjelaskan tentang hasil penelitian dan pembahasan dari judul yang diangkat dalam penelitian. Hasil penelitian ini berupa data deskritif mengenai keberhasilan dalam berwirausaha ternak burung Lovebird.

\section{Deskripsi Objek Penelitian}

Usaha burung Lovebird milik Bapak Heli merupakan usaha di lahan pekarangan rumah. Di lahan kosong inilah dibangun sebuah bangunan permanen yang akan digunakan sebagai tempat penangkaran Lovebird. Alasan memilih lokasi karena akses dan jarak yang memudahkan kontrol dari perkembangan bisnis peternakan ini.Usaha ini merupakan usaha perorangan dengan menggunakan modal sendiri. Usaha penangkaran burung Lovebird telah ditekuni oleh Bapak Heli sejak tahun 2008 dengan menggunakan modal sebesar Rp 8.000.000 Modal ini diperoleh dari menyisihkan sedikit gajinya sebagai satpam di lapangan Golf Bumi Sendangmulyo Klipang . Dengan modal ini Bapak Heli membeli sarana dan prasarana guna menunjang usahanya serta membeli indukan dari pedagang atau pengepul di Pasar Burung.

Pada tahun 2009 Bapak Heli menekuni usaha budidaya burung Lovebird khususnya burung Lovebird kacamata.Saat itu, budidayanya masih dalam tahap percobaan dengan tujuan untuk mengetahui sistem budidaya burung Lovebird kacamata yang baik sehingga dihasilkan burung berkualitas.Awalnya budidaya ini hanya sebagai pekerjaan sampingan.Kemudian usaha ini terus berkembang hingga akhirnya jumlah kandang ternak yang dimiliki ada 50 pintu.Hal ini dilakukan secara bertahap dengan menginvestasikan setiap hasil penjualan untuk penambahan kandang ternak. Namun, pada tahun 2010 Bapak Heli memfokuskan untuk mengusahakan burung Lovebird. Berdasarkan hasil wawancara hal ini dilakukan karena permintaan terhadap burung 
Lovebird lebih stabil dibandingkan dengan burung kicau lainnya.Fasilitas yang digunakan pada usaha ini adalah kandang ternak, kandang soliter, kandang umbaran, listrik dan air, telepon, bangunan permanen, dan peralatan kebersihan.

Hasil produksi usaha Bapak Heli hanya dijual kepada pengepul.Pengepul tersebut berjumlah dua orang.Setiap pengepul membeli langsung ke tempat usaha, sehingga usaha ini tidak mengeluarkan biaya pengiriman.Pengepul-pengepul ini merupakan pelanggan tetap usaha Bapak Heli.

\section{Varian Lovebird yang di budidayakan Bapak Heli}

1. Lovebirdparblue pastel

Harga : 2- 3 jutaan anakaan

Gambar 4.1

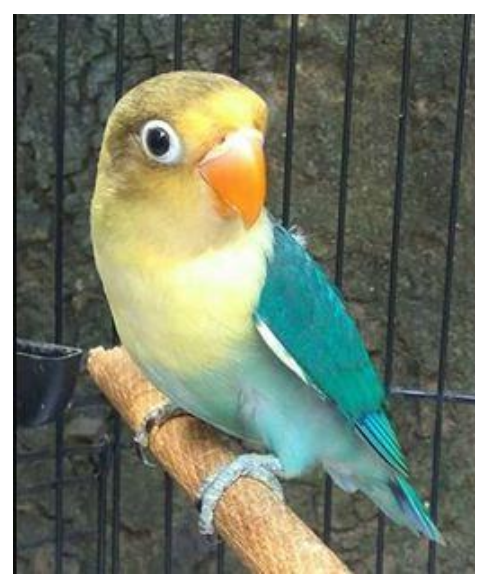

2. Lovebird Blorok

Harga : Berkisaran antara 1,5jt -keatas

\section{Gambar 4.2}

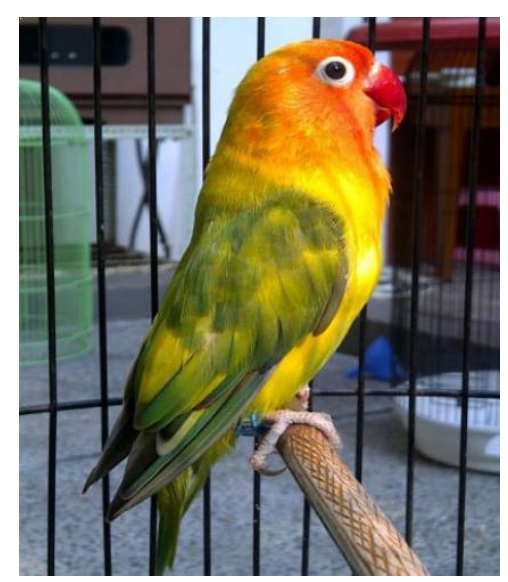




\section{Lovebird Biola}

\section{Gambar 4.3}

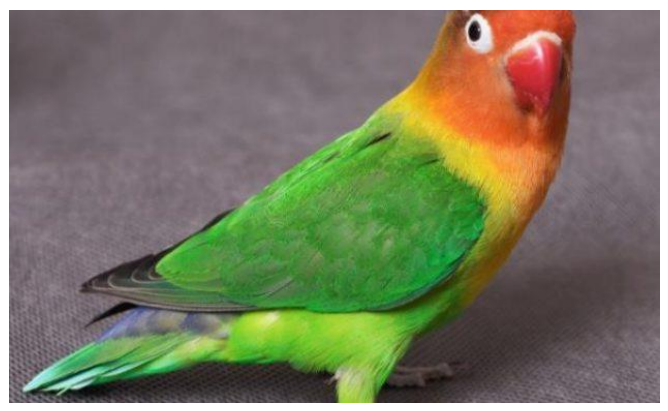

Harga : berkisaran antara 5jt-keatas

\section{HASLI WAWANCARA}

Untuk mengetahui hasil dari penelitian tentang peternakan burung lovebird ini pada usaha Bapak Heli,di lakukan wawancara mendalam dengan informan dan pengamatan langsung di lapangan guna memperoleh informasi yang jelas dan akurat tentang kondisi yang sesungguhnya.dalam penelitian kualitatif ini peneliti menggunakan Tabulasi dengan metodeTraingulasi.Seperti terlihat dalam table 2

Tabel 2

Tabulasi Hasil Wawancara dengan METODE TRAINGULASI

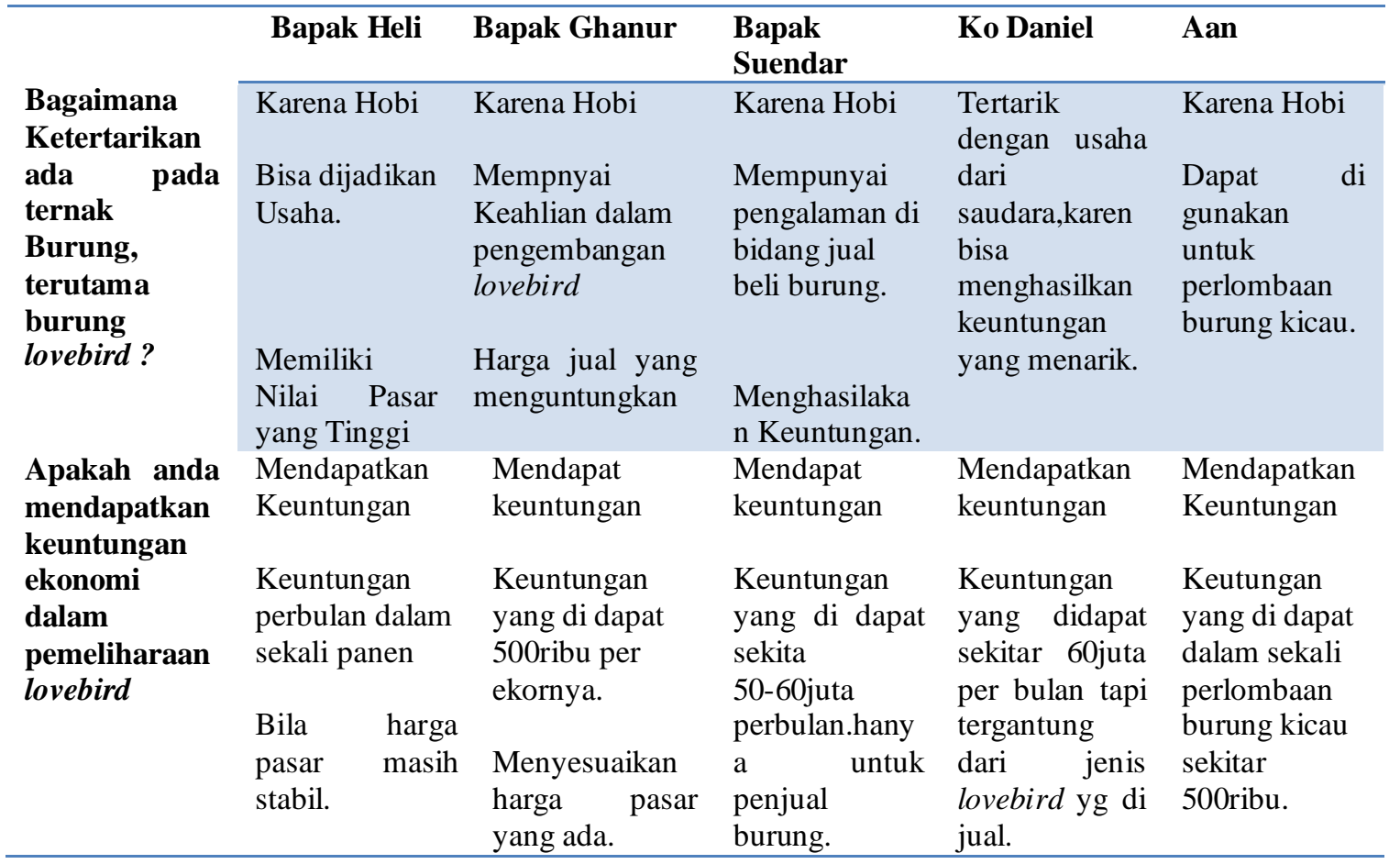




\begin{tabular}{lllllllll}
\hline $\begin{array}{l}\text { Apakah } \\
\text { Penyebab }\end{array}$ & Sudah banyak & Setiap musim & Minat beli & Stock & Harga & Pasar \\
yang & burung & hujan anakaan & menurun pada & ternakan & yang & sudah \\
membuat & lovebird yang & resiko mati tinggi & tertentu. & minat beli & \\
harga lovebird & saat itu harga & & & & turun maka & \\
turun dan & masih tinggi. & & & & harga turun & \\
tingkat & & & & agar cepat & \\
pembelian & & & & laku. & \\
berkurang & & & & & \\
\hline
\end{tabular}

\section{Pembahasan}

\section{Analisis Aspek Non finansial}

Analisis ini bertujuan untuk menilai kelayakan usaha burung Lovebird milik Bapak Heli dari aspek non finansial. Pada penelitian ini aspek non finansial yang akan dianalisis antara lain aspek pasar, aspek teknis, aspek manajemen dan hukum, serta aspek sosial dan lingkungan. Berikut penjelasan tentang aspek-aspek yang dianalisis:

\section{Aspek pasar}

Pasar berkaitan dengan kelangsungan produksi suatu usaha, sehingga hal ini menjadikan pasar sebagai suatu aspek penting. Suatu usaha akan memperoleh keuntungan jika pasar menyerap hasil produksi dalam jumlah yang tinggi. Sebaliknya, jika pasar menyerap hasil produksi dalam jumlah yang rendah maka suatu usaha akan memperoleh kerugian. Pada penelitian ini hal yang dianalisis adalah permintaan dan penawaran serta pemasaran yang dilakukan oleh usaha Bapak Heli.

\section{Permintaan dan penawaran}

Penjualan burung Lovebird merupakan sumber pendapatan utama pada usaha Bapak Heli . Setiap hasil produksi akan dijual kepada pengepul. Jadi, berapa pun hasil produksinya akan habis terjual. Jumlah burung yang ditawarkan rata-rata mencapai 25 ekor per bulan dan jumlah burung yang diminta rata-rata mencapai 100 ekor per bulan untuk peternakan miliknya sendiri.Hal ini merupakan peluang bagi usaha Bapak Heli karena ada permintaan yang belum terpenuhi, yaitu sekitar 75 ekor per bulan.Burung Lovebird yang dijual merupakan burung yang berumur minimal 2 bulan dengan harga yang ditawarkan rata-rata, yaitu Rp 1.000.000 per ekor.Penjelasan lebih lanjut berkaitan data penawaran dan permintaan usaha milik Bapak Heli dapat dilihat pada Tabel 3. 
Tabel 3

Data permintaan dan penawaran usaha milik Bapak Heli

\begin{tabular}{|l|l|l|l|l|l|l|}
\hline No & \multicolumn{1}{|c|}{ Pelanggan } & status & Kota asal & $\begin{array}{c}\text { Permintaan } \\
\text { per bulan } \\
\text { (ekor) }\end{array}$ & $\begin{array}{c}\text { Penawaran } \\
\text { per bulan } \\
\text { (ekor) }\end{array}$ & $\begin{array}{c}\text { Presentase } \\
\text { terpenuhi } \\
(\%)\end{array}$ \\
\hline 1 & Ghanur ex'as & pengepul & Semarang & 25 & 10 & 40 \\
\hline 2 & Suendar & Pengepul & Semarang & 50 & 10 & 20 \\
\hline 3 & Ustadlovebird & Peternak & Semarang & 25 & 5 & 20 \\
\hline & & Total & & 100 & 25 & \\
\hline
\end{tabular}

Sumber : Data primer yang diolah (2015)

\section{Pemasaran output}

1. Produk

Produk yang dihasilkan oleh penangkaran Bapak Heli adalah anakan burung usia 2 bulan dengan berbagai varian warna. Pada usia 2 bulan ini anakan burung sudah dapat hidup mandiri dan pisah dari induknya.

\section{Harga}

Penetapan harga yang dilakukan oleh penangkaran milik Bapak Heli didasarkan pada harga yang ditentukan oleh pesaing, harga pokok produksi dan jenis LB(lovebird). Harga anakan burung Lovebird jenis Biola contohnya yang berumur dua bulan yaitu Rp 5.000.000 per ekor.

\section{Promosi}

Promosi dilakukan lewat media sosial, seperti facebook ,OLX dan instagram. Jalur promosi ini dianggap sebagai promosi yang efektif dan efisien.

4. Saluran

Bapak Heli menjual hasil produknya kepada pengepul.Biasanya para pembeli datang langsung ke tempat budidaya Lovebird milik Bapak Heli ini. Hal ini dilakukan agar pembeli dapat melihat secara langsung burung yang akan dibeli. Para pelanggan ini sebagian besar dari wilayah Semarang. Pemasaran output pada usaha Bapak Heli ini dapat dilihat pada 


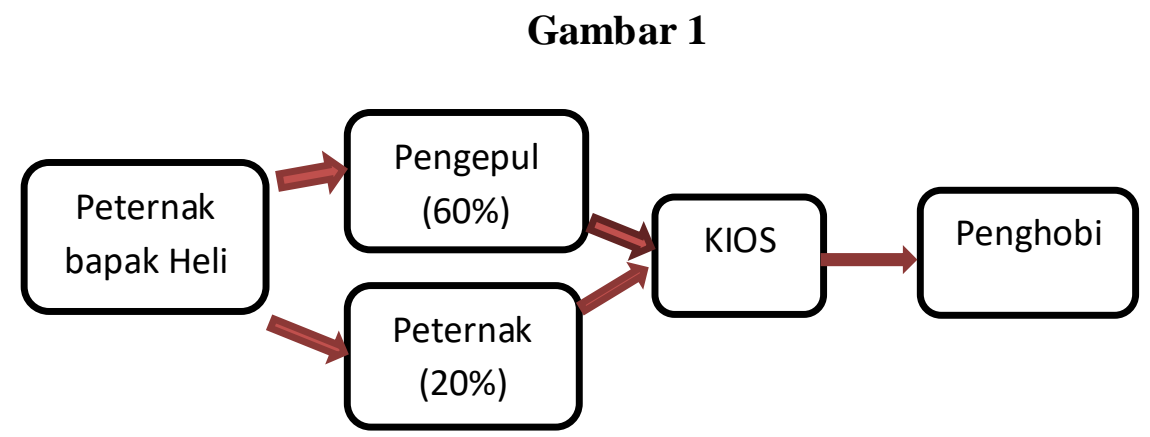

Berdasarkan analisis aspek pasar usaha burung Lovebird milik Bapak Heli layak untuk dijalankan.Hal ini dilihat dari adanya excess demand atau permintaan output yang dihasilkan dan masih ada permintaan yang belum terpenuhi. Selain itu, usaha ini sudah memiliki pelanggan tetap, sehingga berapa pun output yang dihasilkan akan habis terjual.

\section{Aspek teknis}

Analisis aspek teknis berpengaruh terhadap kelancaran proses produksi suatu usaha. Pada penelitian ini analisis aspek teknis meliputi perencanaan lokasi, pemilihan peralatan dan teknologi yang digunakan, serta layout. Berikut penjelasannya:

\section{Perencanaan lokasi usaha}

Ada beberapa hal yang dipertimbangkan dalam perencanaan lokasi usaha Bapak Heli, yaitu sarana jalan, ketersediaan tenaga kerja, sarana penunjang, serta aspek iklim dan aspek agronomis. Pertama, lokasi usaha ini sudah memiliki sarana jalan yang memadai.Jalan menuju lokasi merupakan jalan aspal, sehingga hal ini dapat memudahkan kegiatan usaha.Kedua, tenaga kerja ini dilakukan oleh bapak Heli dan satu karyawannya karena masih mampu untuk di kerjakan untuk 2 orang saja.Ketiga, tersedianya sarana penunjang seperti air, listrik, dan telepon.Pada usaha ini sarana tersebut sudah tersedia dan tidak sulit untuk memperolehnya. Keempat, aspek iklim dan aspek agronomis berkaitan dengan proses produksi. Lokasi usaha ini memiliki suhu sekitar $25-28^{8} \mathrm{C}$ dalam keadaan ini sangat cocok untuk burung beradaptasi dan berkembang biak.

\section{Budidaya burung Lovebird}

Budidaya merupakan sistem produksi yang mencakup input produksi (prasarana dan sarana produksi), proses produksi (persiapan hingga pemanenan), dan output produksi (penanganan pasca panen dan pemasaran). Saat ini budidaya burung Lovebird 
belum memiliki SNI (Standar Nasional Indonesia) jadi tidak ada aturan khusus yang mengatur ketentuan untuk membudidayakan burung ini.

Burung Lovebird memiliki siklus produksi selama 3 bulan. Berikut budidaya burung Lovebird yang dilakukan oleh usaha Bapak Heli :

\section{Pengadaan sarana dan prasarana produksi}

Kandang yang digunakan untuk pemeliharaan burung Lovebird sangat beragam dan disesuaikan dengan lahan yang ada.Ukuran kandang yang digunakan sangat bervariasi.Belum ada ketentuan yang mengatur ukuran dan bentuknya, serta belum ada juga laporan tentang pengaruh perbedaan bahannya terhadap kehidupan burung.Pada usaha burung Lovebird milik Bapak Heli, kandang yang digunakan untuk pemeliharaan terbuat dari kayu dan kawat jaring.Bahan dan peralatan yang digunakan adalah palu, paku, tang, dan gergaji. Untuk pakan utamanya sehari-hari menggunakan biji - bijian berupa millet puth dan millet merah, sedangkan pakan tambahannya menggunakan jagung muda dan kangkung yang dipotong-potongSedangkan untuk burung yang sudah terjangkit penyakit maka akan dikarantina dan harus dijauhkan dari burung sehat lainnya guna mencegah penularannya. Kemudian diberikan obat yang sesuai dengan jenis penyakit yang menyerang burung tersebut.Selain itu, usaha ini juga menjaga kebersihan fasilitas-fasilitas yang digunakan dan menjaga kualitas kandang.Penjagaan fasilitas-fasilitas dilakukan dengan selalu membersihkan alas kandang atau peralatan terutama tempat pakan dan minum.

\section{b. Proses produksi}

Burung Lovebird memiliki siklus produksi selama 3 bulan.Burung yang digunakan sebagai indukan adalah burung yang sudah berumur 1 tahun serta tidak cacat fisik dan memiliki warna yang cerah.Perbandingan pejantan dengan indukan yang digunakan adalah 1:1. Proses pertama adalah pengenalan dan penjodohan. Pejantan dan betina diletakkan dalam kandang soliter kemudian didekatkan satu sama lain tanpa burung tersebut melihat burung yang lainnya, setelah beberapa hari burung akan saling bercumbu dan saling manja. Itulah salah satu tanda bahwa burung siap dimasukkan kedalam kandang ternak Setelah sarang rapi maka burung akan bertelur dan mengerami telurnya selama 21 hari. Proses pengeraman dilakukan secara bergantian oleh pejantan maupun indukan oleh sebab itu proses produksi ini menggunakan perbandingan 1:1. 
Selama proses pengeraman ini burung sebaiknya dihindarkan dari gangguan manusia maupun hewan pemangsa karena apabila terdapat gangguan maka biasanya burung ini tidak mau lagi untuk mengeram. Pakan harus selalu tersedia karena apabila habis maka ada risiko indukan akan mati karena asupan pakannya kurang dan berdasarkan pengalaman peternak, burung yang sedang mengeram mengeluarkan panas tubuh yang lebih tinggi dari biasanya sehingga dibutuhkan asupan pakan yang cukup dan bergizi, selain itu burung yang sedang mengeram lebih cenderung jarang keluar dari tempatnya mengeram.Biasanya bapak heli meakukan perkawinan silang contonya yaitu seperti burung lovebirdewing di jodohkan dengan jenis lovebird Biola maka telur yang dihasilkan adalah lovebird jenis biolaewings dan menghasilkan varian yang baru dan bisa untuk di kembangkan bilamana pasar dapat menerima.

\section{Penanganan pasca panen}

Setelah 21 hari pengeraman maka telur akan menetas dan anakan yang baru menetas akan disapih oleh induknya sampai anaknya berumur 1 minggu. Penyepetan yang biasa bapak heli aitu umur 1 minggu karena saat umur tersebut saat di sapih oleh pemilik maka indukaan akan mulai proses produksi lagi maka akan mempercepat hasil panen miliknya.Pada saat umur seminggu anakan akan diambil dan dibesarkan sendiri oleh Bapak Heli agar mendapat asupan yang cukup dan merata ke setiap anakan, karena biasanya anakan yang diloloh oleh induknya akan berbeda pertumbuhannya karena adanya persaingan dengan saudaranya,. Asupan tambahan yang diberikan Bapak Heli berupa bubur bayi yang mengandung beras merah dan kedelai.Karena berdasar pengalaman, pakan tambahan seperti itu paling bagus untuk anakan. Saat berusia 2 bulan maka anakan siap untuk dipanen dan akan dilakukan penyortiran untuk memisahkan antara burung yang akan dijual dengan burung yang tidak akan dijual,. Burung yang akan dijual kemudian diletakkan di kandang umbaran yang luasnya $4 \mathrm{~m} 2$, tujuan dari kandang umbaran ini adalah untuk melatih terbang burung anakan supaya pernapasannya bagus. Kriteria dari burung kicau agar merdu suaranya adalah dari nafas burung tersebut. Saat semua burung sudah siap untuk dijual maka Bapak Heli akan menghubungi para pengepul. Pengepul bebas untuk memilih burung mana yang akan dibeli dan biasanya mereka sudah menyiapkan wadah atau kandang untuk membawa 
anakan burung yang mereka pilih. Karena pengepul memantau langsung kondisi burung sebelum dibeli dan mereka bebas memilih maka Bapak Heli tidak memberikan garansi

\section{Tata letak (layout)}

Layout merupakan suatu proses dalam penentuan bentuk dan penempatan fasilitas-fasilitas yang dimiliki suatu perusahaan. Dalam budidaya burung Lovebird penentuan bentuk dan penempatan sarana dan prasarana disesuaikan dengan lahan yang ada. Jadi, belum ada ketentuan yang mengatur tata letak yang baik dalam budidaya Pada usaha ini kandang yang digunakan sebagai tempat pengawinan berukuran $50 \mathrm{~cm}$ x 50 $\mathrm{cm}$ x $50 \mathrm{~cm}$. Bentuk dan ukuran kandang yang dipilih serta penempatannya telah disesuaikan dengan lahan yang ada. Berikut layout usaha burung Lovebird milik Bapak

Berdasarkan analisis aspek teknis, usaha burung Lovebird milik Bapak Heli dinyatakan layak untuk dijalankan karena lokasi usahanya sesuai untuk memproduksi burung Lovebird.Selain itu, lokasi usahanya juga memiliki sarana jalan yang memadai, memiliki sarana listrik, air, dan telepon, serta memiliki kemudahan dalam memperoleh tenaga kerja. Selanjutnya, karena budidaya burung Lovebird belum memiliki SNI (Standar Nasional Indonesia) maka budidaya yang dilakukan usaha Bapak Heli sama dengan budidaya yang dilakukan oleh penangkar burung Lovebird pada umumnya.

\section{Aspek manajemen}

Usaha burung Lovebird milik Bapak Heli sudah memiliki pembagian kerja antara lain 1 karyawan. Dengan adanya pembagian kerja, setiap pekerja akan menjalankan tugas dan kewajibannya sesuai dengan pembagian kerja yang telah diberikan. Dalam hal ini setiap aktivitas-aktivitas akan diawasi dan dikontrol oleh Bapak Heli selaku pemilik usaha.Berdasarkan analisis aspek manajemen usaha burung Lovebird milik Bapak Heli dinyatakan layak karena usaha ini sudah menerapkan fungsi-fungsi manajemen menurut Rahardi et al. (1993), yaitu perencanaan, pengorganisasian, pergerakan, dan pengawasan dalam manajemen produksi, manajemen pemasaran, dan manajemen keuangan.

\section{Aspek hukum}

Setiap usaha memiliki ketentuan hukum yang berbeda-beda tergantung dari jenis usahanya.Ketentuan hukum merupakan hal yang harus dipenuhi sebelum menjalankan suatu usaha agar dikemudian hari bisnis tidak terbentur dengan permasalahan hukum 
atau perizinan.Usaha ini belum terdaftar sebagai salah satu usaha perburungan di wilayah Kota Semarang dikarenakan usaha ini hanya usaha perseorangan dan belum memiliki bentuk usaha. Sehingga untuk pajak yang dikenakan kepada usaha budidaya Lovebird milik Bapak Heli adalah pajak penghasilan sebesar satu persen dari omset atau penerimaan kotor berdasarkan Peraturan Pemerintah No. 46 Tahun 2013 tentang pajak penghasilan atas penghasilan dari usaha yang diterima atau diperoleh wajib pajak yang memiliki peredaran bruto tertentu.

\section{Aspek sosial dan lingkungan}

Jika dilihat dari aspek sosial, keberadaan usaha Bapak Heli dapat mengurangi pengangguran dimana mempekerjakan saudaranya untuk membantu usaha ini, yaitu satu orang dan pemilik usaha.Kegiatan usaha ini menghasilkan limbah organik yang berasal dari kotoran burung dan sisa pakan alami. Limbah-limbah ini akan terurai dengan tanah, sehingga tidak berdampak buruk terhadap lingkungan dan selama ini belum ada keluhan dari warga sekitar. Usaha ini juga selalu menjaga kebersihan lingkungan dengan membuang limbah pada tempatnya dan menjaga kebersihan selokan-selokan di sekitar usaha yang digunakan sebagai pengairan dari usaha ini, sehingga pengairannya berjalan dengan lancar.Dengan demikian, usaha ini layak untuk dijalankan dari aspek sosial dan lingkungan sebab keberadaan usaha ini dapat memberikan manfaat terhadap warga sekitar, serta baik untuk kelestarian lingkungan, sehingga usaha ini masih tetap bisa berjalan hingga sekarang.Berdasarkan hal tersebut, usaha ini layak untuk dijalankan dari aspek sosial dan lingkungan.

\section{KESIMPULAN}

Dari hasil penelitian usaha penangkaran burung Lovebird milik Bapak Heli dapat disimpulkan bahwa berdasarkan kriteria aspek non finansial usaha burung Lovebird layak untuk dijalankan.Dilihat dari aspek pasar, usaha ini memiliki peluang pasar yang cukup besar karena permintaan burung Lovebird di peternakan Bapak Heli cukup tinggi. Berdasarkan aspek teknis, usaha ini layak dijalankan karena memiliki letak yang strategis, proses produksi yang baik serta kesesuain lokasi seperti iklim, cuaca, suhu dan air untuk kegiatan produksi burung Lovebird. Dari aspek sosial, usaha burung Lovebird ini memberi manfaat pada kesejahteraan bagi masyarakat dengan memberi pekerjaan bagi warga sekitar lokasi usaha.Untuk aspek manajemen, usaha burung Lovebird ini 
telah dikelola secara baik dengan adanya pembagian kerja dan penempatan tenaga kerja pada ahlinya.Dari aspek lingkungan menunjukkan usaha ini peduli terhadap keadaan lingkungan, dimana usaha ini tidak membawa dampak negatif terhadap lingkungan.

Hasil analisis Sensitifitas, usaha penangkaran burung Lovebird milik Bapak Heli secara umum dapat disimpulkan bahwa bisnis penangkaran burung Lovebird ini sangat sensitif terhadap penurunan jumlah produksi.

\section{DAFTAR PUSTAKA}

Dewi S. 2011. Rahasia sukses beternak burung Lovebird.Yogyakarta.Pustaka Baru Press.

Winata, N. 2012.Analisis kelayakan usaha peternakan Lovebird pada Tasya Lovebird, Kartasura [skripsi]. Surakarta (ID): Universitas Muhammadiyah

Sujana 2016, Analisis Studi Kelayakan Bisnis Penangkakaran Burung Murai Batu Sumatra.Skripsi Universitas tarumanegara Surakarta.

Fathurohman 2014.Analisis Kelayakan Ternak Burung Puyuh Di DEsa Pasir Kawung Cileunyi Kabupaten Bandung.Sekripsi Institut Nasional Bandung.

Suradi.2017. Analisis usaha ternak burung jalak uren di desa jimbung kecamatan kalikotes kabupaten klaten : Universitas Muhammadiyah

Abbas, Hanif. 2005. Pengantar Ilmu Peternakan. Padang : Universitas Andalas.

Ibrahim Y. 2003. Studi Kelayakan Bisnis. Jakarta (ID): Rineka Cipta.

Made GB. 2005. Analisa Kelayakan Bisnis Usaha Pembudidayaan Ikan Koki Pada Lahan Terbatas di Jakarta [tesis]. Bogor: Sekolah Pasca Sarjana, Institut Pertanian Bogor.

Sitanggang M, Yudiantoro. 2011. Lovebird Sicantik Bersuara Merdu. Jakarta: PT AgroMedia Pustaka. 
Majalah Ilmiah Solusi

Vol. 17, No. 2 April 2019

ISSN : 1412-5331

" Halaman ini sengaja di kosongkan " 